\title{
Environmental impacts of organic agriculture and the controversial scientific debates
}

\author{
Emil Debuschewitz $\cdot$ Jürn Sanders
}

Received: 7 June 2021 / Accepted: 27 December 2021 / Published online: 10 February 2022

(C) The Author(s) 2022

\begin{abstract}
The environmental impacts of organic agriculture have been controversially discussed in the scientific community for many years. There are still conflicting views on how far organic agriculture can help address environmental and resource challenges, and whether its promotion is an appropriate policy approach to solving existing socioecological problems. So far, no clear perspective on these questions has been established. How can this be explained? And is there a "lock-in" of the scientific discourse? The aim of this paper is to retrace the scientific discourse on this topic and to derive possible explanations as to why environmental impacts of organic agriculture continue to be assessed differently. To this end, a qualitative content analysis was conducted with a sample of $n=93$ scientific publications. In addition, expert interviews were conducted to verify the results of the literature analysis. Two main lines of discussion were identified: first, the extent to which aspects of food security should be included in the assessment of environmental aspects (thematic frame); second,
\end{abstract}

Supplementary Information The online version contains supplementary material available at https://doi. org/10.1007/s13165-021-00381-z.

E. Debuschewitz $(\bowtie) \cdot$ J. Sanders

Thünen Institute of Farm Economics, Bundesallee 63,

38116 Braunschweig, Germany

e-mail: emil.debuschewitz@posteo.de

J. Sanders

e-mail: juern.sanders@fibl.org the extent to which net environmental impacts or possible leakage effects because of lower yield levels should be considered (spatial frame). It is concluded that the polarizing debate mainly results from the often-binary initial question (is organic agriculture superior to conventional agriculture?). Further, aspects that have been insufficiently illuminated so far, such as the choice of reference units or normative basic assumptions in scientific sustainability assessments, should be given greater consideration in the discourse.

Keywords Lock-in · Sustainable agriculture · Leakage effects · Reference unit · Binarity $\cdot$ Research framing

\section{Introduction}

Organic agriculture (OA) is considered a particularly environmentally friendly way of farming based on the interconnected principles of health, ecology, fairness, and care (IFOAM 2021). Especially in the European Union (EU), policymakers have therefore advocated an expansion of the area under organic management. In Germany, for example, a growth target was set in 2001: the aim is to achieve a $20 \%$ share of organically managed land (BMEL 2019). More recently, the EU Commission's Farm to Fork Strategy has called for at least $25 \%$ of agricultural land in the EU to be farmed organically by 2030 , in view of the expected positive 
environmental and resource-related effects (European Commission 2020).

The political support of OA and its advantages in environmental protection have been the subject of intense political and scientific discussions for more than twenty years (Sanders 2016). Repeatedly, several scholars have provided empirical evidence for the relative advantages of OA (cf. Reganold and Wachter 2016; Stolze 2000), whereas others have produced contrary findings and concluded the opposite (cf. Bergström and Kirchmann 2016; Trewavas 2001).

Thus, there is reason to assume that scientific debates on the relative merits of OA have taken place in an overall fruitless way since the beginning of the political support debates. This is especially true for the question of what role OA is to play nationally and internationally in addressing the critical socioecological problems facing agriculture. ${ }^{1}$ In this context, there is an urgent need to solve such environmental issues related to critically exceeded planetary boundaries, as proposed by Steffen et al. (2015), that are primarily impacted by agriculture, e.g., biosphere integrity and biogeochemical flows. This highlights the importance of science being able to provide clear and welljustified conclusions about environmental impacts of alternative agricultural systems. The question thus arises as to whether there is a "lock-in" of scientific debate.

Against this background, this paper does not provide additional evidence whether or in which areas OA provides greater environmental performance than conventional agriculture (CA). Rather, it attempts to analyze comprehensively the controversial

\footnotetext{
1 Today, the scope of agricultural production is extended far beyond the provision of food and includes numerous environmental and resource-related challenges. In a global context, agriculture's most critical environmental impacts include soil and water degradation, habitat fragmentation and biodiversity loss, freshwater withdrawal, disrupted nitrogen and phosphorus cycles, and greenhouse gas emissions (Foley et al. 2011). At the same time, hunger is on the rise again with over 800 million people undernourished or lacking sufficient nutrients, while overweight and obesity are also increasing rapidly across the globe, leading to a "triple burden" of malnutrition (Gómez et al. 2013; HLPE 2017; Ingram 2020). Such challenges increasingly gain traction in science and policy arenas, not least due to the overarching debate on climate change, making evident the interconnectedness between global warming and food systems and thus its socioecological consequences (IPCC 2019).
}

assessments of OA in scientific debates in terms of the underlying argumentation. Further, it explores the question of why such disparate views still exist in the scientific community. Specifically, the aim of this paper is to retrace the scientific discourse on this topic in order to derive possible explanations why environmental impacts of OA continue to be assessed controversially in the scientific community.

\section{Material and methods}

Systematic literature search

The analyzed material is scientific publications that were obtained through a systematic literature search. The literature search was based on the four-phase flow diagram of the PRISMA Statement ${ }^{2}$ (cf. Moher et al. 2009) and is illustrated in Fig. 1. It consisted of a search string-based query ${ }^{3}$ of the online database Scopus $(n=22$ cases) and a complementary webbased search via Google and Google Scholar, mainly using the snowball system ( $n=71$ cases $)$.

The search string query was conducted in English as it could be assumed that the publications relevant to the discourse to be analyzed are mainly written in English. The search string was not limited to specific environmental dimensions as the interest in knowledge was focused on argumentations that move across different performance areas. Further, it was assumed that the term "yield" is a strong indicator of a publication's relevance to the subject matter, as studies that do not consider yield in any form are unlikely to comprehensively address the question of how to evaluate environmental performance and impacts of any agricultural system.

The complementary search was intended to include relevant literature not captured by the Scopus inquiry, as well as literature that is not subject to peer-reviewed publication but contributes to the debates under investigation. In total, the dataset

\footnotetext{
2 The PRISMA (Preferred Reporting Items for Systematic Reviews and Meta-Analyses) Statement comprises guidelines that address conceptual and practical advances in the science of systematic reviews (cf. Moher et al. 2009).

3 Search string (applied on 28/01/2020): TITLE-ABS-KEY (("organic farm*” OR "organic agricul*") AND ("environment* impact" OR "environment* effect”) AND yield).
} 
Fig. 1 Flow diagram of the systematic literature search combined of a string-based Scopus search and a webbased search (modified according to Moher et al. (2009))

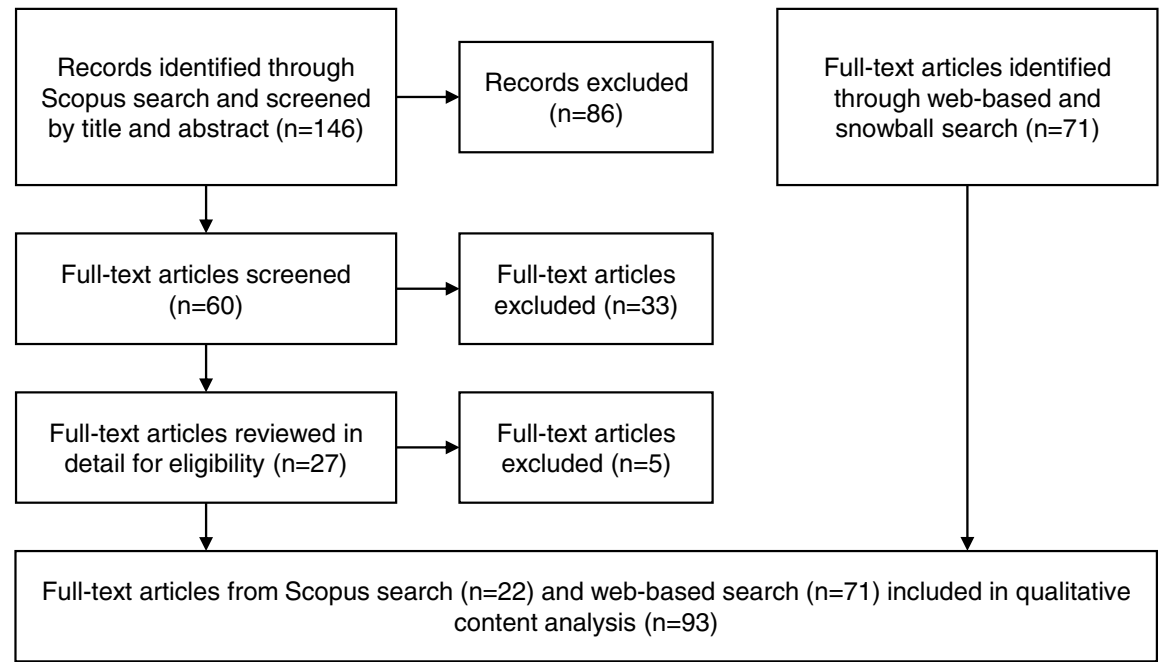

consisted of $n=93$ scientific publications. The full record of the analyzed cases is provided in Online Resource 1.

\section{Qualitative content analysis}

To obtain the desired information from the retrieved cases, a qualitative content analysis was carried out. The content structuring qualitative content analysis applied here is based on Mayring (2015) and Kuckartz (2018). The analysis was conducted using the data analysis software MAXQDA 2020 (VERBI Software 2019). To obtain the content-related information from the analysis units, i.e., scientific publications, these were coded, which is equivalent to categorizing text segments (Kuckartz 2018). The codebook (including the coding frame with all main and sub-codes that were used and the code descriptions with application examples) is provided in Online Resource 2.

Due to the explorative and descriptive orientation of the research aim, a mixed form of a-priori code creation and code creation directly on the material, i.e., deductive-inductive coding, was applied (Kuckartz 2018). The starting point for code creation was a coding frame consisting of relatively few codes, which were derived from the first examination of texts during the process of literature search as described above. Central publications in this examination were Gomiero et al. (2011), Meemken and Qaim (2018), and Sanders and Heß (2019).

\section{Expert interviews}

In addition to the scientific publications, qualitative data were obtained in four expert interviews. The interviews specifically aimed at exploring i) possible explanations for the course of the scientific debates and ii) lessons to be learned for the ongoing discourse.

The interviewees were considered suitable experts based on their academic careers and scientific research that has contributed and is closely related to the debates under investigation. All interviewees hold professorships at various international universities, including the research areas of organic agriculture, sustainable land use and food systems, ecology, agricultural economics and development, and sustainability science.

The interviews were conducted via video calls and followed a semi-structured guideline to meet the explorative research objective. All the interviews took place after the literature analysis had been completed. The transcripts of the interviews (provided in German language in Online Resource 3, including the transcription system in Table S1) were then qualitatively analyzed.

\section{Results}

The environmental impacts of OA were first comprehensively described by Stolze (2000). Based on the literature available at the time, the authors concluded that OA-like any type of agriculture-entails 
Fig. 2 Two identified lines of discussion that trace back to two key counterarguments against environagriculture (OA). The two lines illustrate the ambiguity regarding the thematic and spatial boundary in the debates. Each box depicts a set of subsumed arguments. A change of color between two boxes indicates the relativization of the preceding one. Mixed-colored boxes indicate that both relativizing and affirming arguments are subsumed in the box.

The terms in bold type are highlighted in italics in the text (own illustration) mental benefits of organic

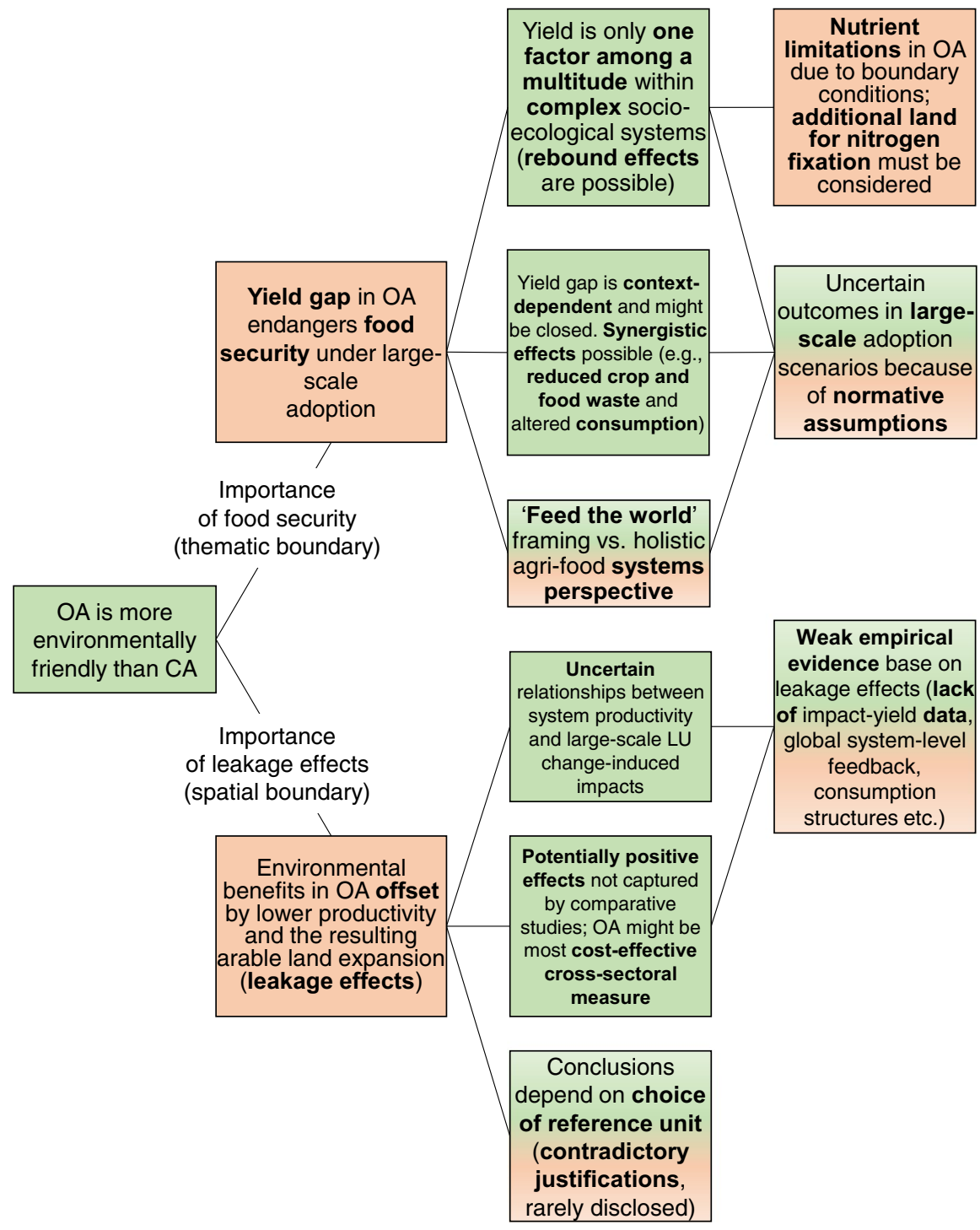

environmental impacts, but that these impacts are less harmful than in CA. This finding was subsequently affirmed by further literature (cf. Gomiero et al. 2011; Reganold and Wachter 2016; Sanders and Heß 2019). However, the conclusion that the environmental performance of OA is superior to that of CA, or simply put, "OA is more environmentally friendly than CA," is not shared by all scientific studies.

Over the past twenty years or so, two key counterarguments have been raised claiming that $\mathrm{OA}$ is not superior to $\mathrm{CA}$ regarding environmental impacts. As discussed further in detail below and illustrated schematically in Fig. 2, numerous studies argue that impacts on food security should be considered in the face of productivity issues when assessing environmental impacts. Second, it is argued that the assessment should also consider potential leakage effects given different land use (LU) efficiencies, i.e., it should not only consider the spatially immediate impacts of organic systems. Based on these intertwined counterarguments, two lines of scientific discussion have emerged in which the two counterarguments are reinforced or relativized, respectively. Thus, the main ambiguity is how broadly to draw the thematic (chapter Importance of food security in assessments of environmental impacts) and spatial (chapter Importance of leakage effects in 
assessments of environmental impacts) frames in the assessments.

\section{Importance of food security in assessments of environmental impacts}

It becomes clear that the first line of argumentation (Fig. 2) can be traced back to the fundamental critique of OA regarding lower productivity. This is commonly considered problematic with reference to increasing population growth and the overarching goal of food security (cf. Goklany 2002; Kirchmann et al. 2007). Consequently, a relevant component of these debates is the yield gap between organic and conventional systems, which are mainly discussed in light of a few key meta-studies (cf. Ponisio et al. 2015; Ponti et al. 2012; Seufert et al. 2012). In addition, the concept of yield stability, i.e., the temporal variability and reliability of production, has been argued to be important when comparing organic and conventional agriculture regarding food security (cf. Knapp and van der Heijden 2018).

In the context of yield gaps, the empirical evidence to date clearly points to lower average yields in OA (cf. Meemken and Qaim 2018). However, beyond averages, it has also been noted that the available data are highly context-dependent, i.e., there is considerable variability depending on system and site characteristics; it is also argued that biases in study selection (e.g., by geographic location) should be taken into account in meta-analyses, as well as the multitude of yield-limiting factors that have been insufficiently understood to date (cf. Lorenz and Lal 2016; Seufert 2019). In general, it is increasingly recognized that yield is only one factor among a multitude of complex economic and ecological interrelationships that need to be included in the sustainability assessment of different farming systems (cf. Ponisio and Ehrlich 2016; Seufert and Ramankutty 2017). This argument has been put forward by researchers calling for a more holistic agri-food systems perspective beyond productivity aspects (cf. IPES-Food 2016) by greater inclusion of ecosystem services (cf. van der Werf et al. 2020) when it comes to assessing the relative merits of alternative farming systems. In particular, it is argued that a primary focus on yields and "eco-efficiency" assessments does not sufficiently address ecological or nutritional issues, as, for example, rebound effects may occur in complex LU systems (cf. Ponisio and Kremen
2016) or efforts to reduce crop and food waste need to be taken into account regarding the goal of food security (cf. Müller et al. 2016).

Accordingly, some researchers emphasize the benefits of OA for sustainable food systems and argue that yield gaps could be closed in the long term if, for example, agroecological conditions and changes in dietary behavior were promoted or possible synergistic effects of large contiguous areas of OA were taken more into consideration (cf. Fess and Benedito 2018; Müller et al. 2017; Ponisio et al. 2015). Others disagree, sometimes vehemently, invoking nutrient limitations in organic systems or the erroneous equation of yield ratios between individual crops with system productivity in some comparative studies, as additional land for nitrogen fixation would be needed in OA (cf. Connor 2018; Kirchmann et al. 2016; Leifeld 2016).

Consequently, the existing limitations of empirical evidence on yield gaps not only influence discussions on food security, but also significantly influence discussions on the assessment of environmental impacts of OA. Although a "conventional wisdom" in scientific discourse has already been described by Holt-Giménez et al. (2012), which advocates a combination of organic and conventional methods with the aim of increasing productivity in a sustainable manner (cf. Meemken and Qaim 2018), this has not led to a reduction in controversial debates. For example, Tal (2018: 9) notes that the binary organic vs. conventional debates foster "a tendency on both sides of the [...] divide to caricaturize the other and cherry pick extreme examples of environmentally problematic practices." Seufert and Ramankutty (2017: 1) also roughly divide the discourse into those researchers promoting $\mathrm{OA}$ as a solution to sustainable food security challenges and others who "condemn it as a backward and romanticized version of agriculture that would lead to hunger and environmental devastation."

Accordingly, along the debates on the role of OA in global food security, arguments have been identified that address the policy relevance of certain scientific issues. In this context, it is striking that the question of whether OA can "feed the world" is a type of framing (cf. IPES-Food 2016) that has persisted throughout the period in which the analyzed literature was published (cf. Goklany 2002; Meemken and Qaim 2018; Müller et al. 2017; Ponti et al. 2012). Again, however, there is disagreement regarding the appropriate focus of research questions. Tittonell (2013), for example, considers the "feed the world" 
framing as oversimplified and thus not very policyrelevant, whereas others argue that this very question is crucial (Niggli 2015) or an interesting thought experiment (Meemken and Qaim 2018).

In addition, there are previously marginalized narratives that argue from the political economy perspective of unequal global power relations, thus criticizing Western industrialized development narratives, and highlighting the importance of food sovereignty (cf. Scoones et al. 2019). Overall, it becomes clear that the discussions about the role of $\mathrm{OA}$ in the context of food security are strongly influenced by normative assumptions on socioeconomic and agricultural development and are correspondingly divergent.

Importance of leakage effects in assessments of environmental impacts

Regarding environmental impacts, which are condensed in a second line of discussion (Fig. 2), the lower yield performance of $\mathrm{OA}$ and the resulting lower land use (LU) efficiency emerge as the main points of criticism, analogous to the first line of discussion. Here, the aspects regarding yield gaps, as described above, are reflected in the use of the concept of leakage effects as a prominent reasoning.

Overall, the discussions on environmental merits of OA predominantly appear as tradeoff analyses. Regarding biodiversity effects, for example, the general argumentation dominates that local biodiversity benefits of $\mathrm{OA}$ are offset or even turn into disadvantages due to higher land requirements when expanded (cf. Tuck et al. 2014). In this context, the logic of leakage effects assumes that an expansion of generally more extensive OA may lead to LU intensification elsewhere, resulting in net negative environmental impacts, e.g., higher greenhouse gas (GHG) emissions through LU change or biodiversity loss through habitat conversion (cf. Bergström and Kirchmann 2016; Gabriel et al. 2013; Kirchmann et al. 2007; Kirchmann 2019; Leifeld 2016; Searchinger et al. 2018).

By the same token, OA is criticized in terms of increased nutrient leaching, assuming that large-scale conversion would lead to arable land expansion to meet the unchanged (or increasing) demand for agricultural products due to yield gaps (cf. Bergström and Kirchmann 2016; Tuomisto et al. 2012). Although there are studies that find lower eutrophication potential in OA (cf. Schader et al. 2012) and more efficient nutrient use on a given area (cf. Mäder et al. 2002; Niggli 2015) due to system boundaries, some researchers also point out that a lack of data, especially on water conservation, does not allow robust general conclusions (cf. Kusche et al. 2019; Seufert and Ramankutty 2017). Further, regarding biodiversity and GHG emissions, estimating the effects of large-scale adoption of OA is argued to be ambiguous because there exists uncertainty about the relationship between yieldlevels and land in production or conversion of natural habitat (cf. Ponisio and Kremen 2016; Reganold and Wachter 2016; van der Werf et al. 2020).

In addition, there are arguments indicating that so far unmeasured and potentially positive effects of OA are not covered by comparative studies conducted to date (cf. Clark and Tilman 2017; Tuck et al. 2014); e.g., positive biodiversity effects from large contiguous areas of OA (cf. Meng et al. 2017; Stein-Bachinger et al. 2019). Hence, some authors argue that expanding OA might be the most cost-effective strategy from the perspective of integrated policy measures that address improvements in multiple environmental dimensions simultaneously (cf. Jespersen et al. 2017).

The role of reference units in environmental impact assessments

What further becomes clear from the above is that study results and their conclusions regarding the benefits of OA significantly depend on the choice of reference unit. That is, whether environmental impacts are expressed per unit of farmed area or per unit of produced output. The central role of the reference units in environmental impact assessments becomes particularly clear regarding nutrient leaching and GHG emissions (cf. Halberg et al. 2005; Schader et al. 2012).

As Meemken and Qaim (2018) summarize, most evidence suggests that OA has lower environmental impacts in terms of GHG emissions when expressed per unit area, and higher impacts per unit output, respectively. However, as Sanders and Heß (2019) point out, in many studies the choice of the appropriate reference unit-despite its centrality to the results and conclusions - is inadequately justified. The latter authors argue that the question of the appropriate reference unit from a societal perspective ${ }^{4}$ needs

\footnotetext{
4 This refers to the environmental dimensions of biodiversity, water protection, climate protection, and climate adaptation. The reference units for assessing impacts on soil fertility (area) and resource ( $\mathrm{N}$ and energy) efficiency (output) were considered immanent (Sanders and Heß 2019).
} 
further scrutiny by considering i) the spatial scope of a solution to reduce environmental impacts (is the public environmental good to be provided on a local or global scale?), ii) the regional characteristics of environmental impacts (how scarce are specific public environmental goods in a region?), and iii) the risk and extent of leakage effects (does the provision of a public environmental good in one region result in negative environmental impacts in another region?).

Regarding the (rarely explicit) backing argumentation for the use of different reference units, contradictory justifications could be identified in the present study. Some scholars argue that the primary use of the output-reference is misleading because absolute, rather than relative (to the yield), environmental impacts are decisive; thus, the primary focus on the output-reference would not do justice to the complexity of goods and services provided as well as to the systems approach of $\mathrm{OA}^{5}$ (cf. Müller et al. 2016; Niggli 2015; Ponisio and Kremen 2016).

On the other hand, it is argued that expressing environmental impacts per unit area is misleading if it does not take into account system productivity (which is usually lower in OA) and LU efficiency; thus, in the context of a growing world population and global environmental impacts, yield units would be the primarily relevant reference (cf. Kirchmann 2019; Meemken and Qaim 2018; Tuomisto et al. 2012). It is noteworthy in this context that already about twenty years ago, Geier (2000) stated that there is no consensus on the use of the functional unit within the life cycle assessment (LCA) methodology ${ }^{6}$ and thus the main problem is the question of when it is reasonable to relate environmental impacts to the output

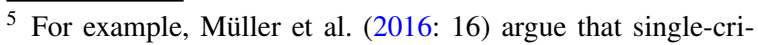
teria assessments such as emissions per unit output disregard negative externalities, e.g., through the production of synthetic inputs or concentrate feed. Similarly, the IPES-Food (2016: 68 ) finds that classical measures of agricultural productivity systematically undervalue benefits of diversified systems; thus, new "measures of success" should be established which account for, e.g., total resource flows and interactions between the agricultural sector and the wider economy.

6 Within the LCA methodology, the term "functional unit" is used (according to the "function" attributed to a studied system) and "serves as the reference basis for all calculations regarding impact assessment" (Arzoumanidis et al. 2020: 1). Thus, in the context of this study, "functional unit" can be considered synonymous with the term "reference unit" (cf. van der Werf et al. 2020).
}

and when to the area. The disparate views on the appropriate choice of reference units that since have been brought forward illustrate the difficulty to debate environmental impacts within consistent thematic and spatial boundaries.

The partly contrary argumentation is aggravated by a weak empirical evidence base on leakage effects that could result from an expansion of OA, especially on a global scale. For example, Seufert and Ramankutty (2017) note that potential impacts of a largescale shift to OA are highly uncertain due to, among other issues, existing knowledge gaps on system-level feedback effects that ultimately influence future food production and demand. Other studies emphasize that regarding leakage effects, analogous to the implications for food security, it is crucial in an assessment of OA to also include dietary habits and the origin of demanded foods (cf. Haller et al. 2020; Müller et al. 2017). Accordingly, the German Advisory Council on Global Change has recently pointed out that the argument of leakage effects cannot be the sole focus when aiming to safeguard globally important ecosystems, but the various dimensions of leakage must be embedded in cross-sectoral measures that go far beyond issues of domestic LU efficiency (WBGU 2020).

\section{Synopsis of the expert interviews}

In addition to the qualitative content analysis of the literature, four expert interviews were conducted and qualitatively analyzed. Across all interviews, it became clear that the nexus of science, policy, and values $^{7}$ that has so far led to research agendas and political initiatives to promote OA (or the general transformation toward sustainable agricultural systems) needs to be adapted to the increasingly complex problem situation described in the Introduction. At the same time, the barriers that might impede such adaptation were addressed. In this context, the interviews also repeatedly referred to the formation of entrenched positions (sometimes referred to as

\footnotetext{
7 As Douglas (2016: 475) states, "Policy influences which science we pursue and how we pursue it in practice, as well as how science ultimately informs policy. Values inform our choices in these areas, as values shape the research agendas scientists pursue, the issues debated as we decide on policy, and what counts as sufficient warrant in any given case".
} 
Table 1 Synopsis of the expert interviews with regard to statements on possible explanations for the controversial scientific debates and on possible ways to alleviate controversy

$\begin{array}{cc}\text { Possible reasons for the course of the debates } & \text {-. The fact that organic farming practices are unified by legal definition, whereas } \\ & \text { conventional ones are not, favors black and white argumentation } \\ & \text {-. Disagreement on normative issues of global agricultural and food systems devel- } \\ & \text { opment (e.g., whether there is a need for productivity increase or the extent to } \\ & \text { which changing dietary patterns and food waste should be included) } \\ \text {-. Path dependencies related to value systems in scientific communities (e.g., regard- } & \text { ing "feed the world" narratives or the notion of naturalness in agricultural systems) } \\ & \text { influence objectivity of research questions } \\ \text {-. Lack of awareness and reflection (especially in natural sciences) about the role of } & \text { framing research and its implications for discourses } \\ \text {-. Increasing influence of different interest groups on academic research as well as } \\ \text { incentive systems of scientific journals perpetuate polarizing debates } \\ \text {-. Fostering context-specific "sustainable" systems that are not necessarily bound to } \\ \text { the regulatory requirements of OA (e.g., hybrid/mixed farming systems, integra- } \\ \text { tion of biotechnology, conservation agriculture) } \\ \text {-. Fora and more frequent opportunities for researchers to exchange across discipli- } \\ \text { nary boundaries to emphasize systems thinking } \\ \text {-. Critical reflection on prevailing (scientific) paradigms and addressing normative } \\ \text { dimensions related to agriculture's role for societal goals }\end{array}$

"paradigms" or "camps") through established academic networks and associated normative foundations that may be dominant in the investigated scientific discourse. The resulting implications are discussed in the chapter Reasons for the lock-in and what to learn from it.

Table 1 shows the synopsis of statements across all interviews that are related to possible explanations for the course of the scientific debates or to possible ways to alleviate the persisting controversies.

\section{Discussion}

Lock-in of scientific discourse

The analysis at hand shows that two lines of discussion have emerged along two main arguments that relativize the environmental performance of $\mathrm{OA}$ in terms of lower productivity. Strikingly, from an argumentative point of view, these lines do not show a substantial development over the course of the last twenty years or so.

Against this background, the present analysis provides evidence for the validity of the assumption formulated at the beginning that the scientific discourse on the relative environmental merits of OA have taken place in an altogether little fruitful manner. In summary, since the beginning of the political support debates, no scientific consensus could be formulated on the extent to which an expansion of organically managed land, which is politically embedded in many places, will help address the environmental and resource challenges.

Certainly, it is not the goal of research to produce as homogeneous scientific knowledge as possible. However, in view of the long period of debates and the partly opposing positions that continue to exist in academic circles, it is remarkable that the productive nature of scientific research in the sense of formulating syntheses has not sufficiently taken place. Given the urgency of environmental and resource problems to be solved and that OA has gained much attention as a possible strategy, the course of scientific debates appears even more problematic.

Thus, we argue that a "lock-in" of scientific debate prevails. Various reasons for and implications of this development are conceivable and will be discussed in the following chapter.

Reasons for the lock-in and what to learn from it

First and foremost, it appears that the binary initial question regarding relative merits of OA compared to CA favors a polarizing discussion space. Accordingly, conclusions are likely to move in dichotomies. This has already been addressed by Mehrabi et al. (2017) in the context of alternative approaches to 
conventional intensification. The authors argue that binary "organic versus conventional" system classifications have exceedingly poor explanatory power; this holds, especially for making clear evidencebased decisions regarding socioecological outcomes of different farming systems on a global scale. Thus, they advocate "more contextual and outcome-based experiments of farming practices" to turn away from "divisive discourse" (Mehrabi et al. 2017: 721) and to promote socioecological benefits of different farming systems.

Further, the expert interviews suggest that the research and development of "hybrid" farming systems might be a way to foster the debates on sustainable agriculture. Other researchers already have called for the deliberate reframing of binary research questions regarding a more differentiated consideration of the multilayered ecological problems and approaches to solutions (cf. Kremen 2015; Seufert and Ramankutty 2017; Shennan et al. 2017). In this context, a final settlement of the "ideologically charged 'organic versus conventional' debate" (Seufert et al. 2012: 231) seems important to avoid fruitless discourse.

Indeed, alternative concepts beyond the organic-conventional dichotomy increasingly diversify both scientific and societal discussions about sustainable agriculture. For example, the agroecology concept is gaining recognition in policy-making (cf. Bisoffi 2019; FAO 2018), but other (partly interrelated) concepts such as conservation agriculture (cf. Kassam et al. 2019; Page et al. 2020), sustainable intensification (cf. Cassman and Grassini 2020; Pretty et al. 2018), ecological intensification (cf. Kernecker et al. 2021; Kremen 2020), or regenerative agriculture (cf. LaCanne and Lundgren 2018; Lal 2020) are also being debated internationally. ${ }^{8}$ However, in the European context, OA continues to be the key benchmark for "greening" conventional systems (WBAE 2020). Regarding the "growing enthusiasm" for regenerative agriculture, Giller et al. (2021: 22), in line with the reasoning of this paper, see "the need for agronomists to be more explicit

\footnotetext{
${ }^{8}$ For a characterization of some of the mentioned concepts, see Garibaldi et al. (2017). For discussions about different perspectives on agricultural intensification to foster sustainability and the associated scientific controversy, see Kuyper and Struik (2014) and Struik et al. (2014).
}

about the fact that many of the [...] dichotomies that frame public, and to some degree the scientific debates about agriculture, have little if any analytical purchase."

Moreover, although the emphasis on inter- and transdisciplinary research (cf. Veerman et al. 2020) to meet the complex problem space seems like a logical conclusion, it can be assumed that it is no panacea. As Bruhn et al. (2019) point out, such endeavors would ideally be structured in a reflexive and cocreative way to advise transformative policy. However, it is not only the issue of lacking standardized frameworks and different traditions and vocabularies of the various disciplines involved (cf. Garibaldi et al. 2017) that needs to be overcome. When operationalizing sustainability in agri-food systems, also different value systems and related normative assumptions of the involved researchers must be considered (cf. Fischer et al. 2014; Halberg et al. 2005; Kuyper and Struik 2014; Thompson 2010).

Consequently, overcoming ideological barriers between supporters and critics of $\mathrm{OA}$ is also recognized as a prerequisite for developing and implementing more sustainable farming systems and their research (cf. Eyhorn et al. 2019; Meemken and Qaim 2018). In general, however, the expert interviews suggest that "path dependencies" regarding certain narratives of agricultural development and a lack of awareness in natural sciences as to how the framing of research questions are embedded in scientific discourse might be major obstacles for such deliberation.

In this context, the argument made by Sanders and Heß (2019) on inadequate justifications for appropriate reference units can be taken further in light of the present results. The backing argumentation, as described in the chapter The role of reference units in environmental impact assessments, reveals that basic normative assumptions in the choice of a reference unit are an implicit part of the discussions and likely are conducive to a polarizing overall debate. For example, there is the question of whether (arable) land is understood as a substitutable input to the agricultural production process or as an integral part of the agroecosystem (cf. Berlin and Uhlin 2004; Tuomisto et al. 2012). Or the question of which "purpose" agricultural systems primarily are to fulfill in the societal context (cf. Leifeld 2016; Ponisio and Kremen 2016) and which framework is to be prioritized in the assessment of environmental 
Table 2 Characterization of different perspectives on agricultural sustainability according to Douglass (1984) and Thompson (2010)

Three schools of agricultural sustainability according to Douglass (1984)

Food sufficiency

This school sees agriculture as an instrument for feeding the world and sustainability is largely a matter of sufficient food production (cf. Halberg 2012; Thompson 2010). "In this group we find the defenders of the modern 'conventional', industrialised agriculture currently represented by the term "sustainable intensification", (Halberg 2012: 984)

Stewardship/ecological integrity In this view, "it is agriculture itself that must be sustainable. It is not simply a matter of agriculture making society sustainable by ensuring that there is enough to eat" (Thompson 2010: 205). Thus, major concerns are the ecological balance and the biophysical limits to agricultural production, which are associated with "environmentalism" (cf. Alrøe et al. 2006; Halberg 2012)

Community/social sustainability "Sustainability as community shares the concern for ecological balance, but with special interest in promoting vital, coherent rural cultures" (Alrøe et al. 2006: 83). It suggests that small-scale, diversified, family-run farms based on self-reliance and holism are more beneficial to sustaining vibrant rural communities than industrially organized farms, thus including "alternative" farming, i.e., the roots of modern OA (cf. Alrøe et al. 2006; Halberg 2012; Thompson 2010)

Two overall concepts for sustainability in agriculture according to Thompson (2010)

Resource sufficiency

Can be described as " "accounting approach' that focuses [...] on how we can measure and calculate the proper balance between present resource use and future needs" based on input/output relations seen from without the system (Alrøe et al. 2006: 83). The LCA method represents a specialized resource sufficiency perspective for environmental assessments (cf. Halberg 2012). Conceptualizations of agricultural sustainability revolve around resource "measurement problems" (Thompson 2010: 240)

Functional integrity

Here, based on an ecological perspective, agricultural sustainability is conceptualized in terms of a system's capacity for self-regeneration, i.e., "Humans and nature form vulnerable socioecological systems that have crucial elements [...] which must be regenerated and reproduced over time" (Alrøe et al. 2006: 83). Hence, this perspective "has strong similarities with the principles of organic agriculture" (Halberg 2012: 984)

impacts accordingly. Here, it becomes clear that different understandings of sustainability are implicitly involved, which can be subsumed under the terms "resource sufficiency" and "functional integrity" (cf. Halberg 2012; Thompson 2010).

Table 2 characterizes these two concepts according to Thompson (2010) and the "three schools of defining agricultural sustainability" (Halberg 2012: 983-984) according to Douglass (1984), on which the former are based.

Importantly, Halberg (2012) recognizes that the different schools of agricultural sustainability according to Douglass (1984) are still present in

\footnotetext{
${ }^{9}$ Note that Müller et al. (2016), for example, use the term "resource sufficiency" for describing approaches that reduce wastage or the consumption of animal products regarding climate change mitigation in food systems. They further argue that for an encompassing sustainability assessment of OA it is crucial to consider not only "efficiency" and "sufficiency" measures but also the "consistency" of resource use, i.e., approaches to optimal resource use that address "the question of the roles different resources play in the context of a sustainable food system" (Müller et al. 2016: 42).
}

contemporary debates, "but many users of the sustainability term seem not to be fully aware of the normative content" (Halberg 2012: 983). Hence, the confounding influence that the sustainability term potentially has on binary scientific debates at hand is pointed out by Seufert (2019: 196): "critics argue that organic agriculture may actually not be more sustainable than conventional agriculture [...]" while advocates of OA "argue that the jury on comparative yields $[\ldots]$ is still out $[\ldots]$ or that yields are not the right metric to assess farming systems by."

However, no substantial discussion of these frameworks, which are influenced by value systems when at work in the assessment of environmental impacts of OA, could be identified in the analyzed literature. It can therefore be assumed that the choice of a reference unit can be an entry point for critical reflection on the inevitable associated normative basic assumptions in environmental impact assessments and that the overall discourse could thus gain in transparency. 


\section{Conclusion}

The paper aimed at retracing the scientific discourse on environmental impacts of $\mathrm{OA}$ and exploring why these continue to be assessed controversially. It could be shown that the debates are characterized by a "lock-in" which is complicated by persisting disagreement in the scientific community on appropriate thematic and spatial boundaries for the assessment of environmental impacts.

We conclude that it appears central to overcome binary questions to alleviate the consequent polarizing logic of the debates under investigation. Thus, the question arises, for example, to what extent comparative case studies that aim to quantify environmental impacts between OA and CA under controlled conditions can make a substantial contribution to the political debate on the future role of OA.

The paper further suggests that the insufficient empirical evidence, particularly on leakage effects and on studies directly linking yield data and environmental impacts on the same fields or farms, complicates the debates. It cannot be assumed, however, that gathering more data will be the sole key to reducing controversy. Consequently, it is increasingly appropriate to discuss the usefulness of research questions by considering a broader view of societies' underpinnings facing increasing global crises. Researchers engaged with environmental impact assessments of agriculture should therefore be aware of their role in the process of co-creating narratives and thus exerting power (cf. Scoones et al. 2019). This is especially true for the implicit operationalization of different sustainability concepts, which is often mediated by the choice of reference units.

Against this background, basic normative assumptions should be more strongly reflected and disclosed when assessing environmental impacts of alternative farming systems. As Nielsen et al. (2019) point out, when considering agricultural LU from the perspective of complex human-environment land systems, there is a need for increased discussion about the normative implications of the scientific research process. Here, it appears crucial to create discussion spaces for agricultural research to appropriately consider the normative aspects that are intrinsic to the sustainability assessments of alternative farming systems. This could make the scientific debates at hand more productive and lead to greater transparency in advising political transformation processes of agri-food systems.

Acknowledgements The authors would like to thank Dr. Christian Schleyer for valuable suggestions on and supervision of the master's thesis that resulted in this paper. Further, the authors would like to thank the reviewers for valuable comments and suggestions on the first draft of the manuscript.

Authors' contributions Both authors contributed to the study conception and design. Data collection and analysis was performed by Emil Debuschewitz. The first draft of the manuscript was written by Emil Debuschewitz and Jürn Sanders commented and partly complemented previous versions of the manuscript. Both authors read and approved the final manuscript.

Funding Open Access funding enabled and organized by Projekt DEAL. The authors have no relevant financial or nonfinancial interests to disclose.

Availability of data and material The analyzed literature is all published literature. A full record list with bibliographic data is available in Online Resource 1. The analyzed interview transcripts are available in German language in Online Resource 3.

\section{Declarations}

Consent for publication All interviewees signed a declaration of consent in which they consented to the anonymized excerpt publication of the collected data.

Conflicts of interest The authors have no conflicts of interest to declare that are relevant to the content of this article.

Open Access This article is licensed under a Creative Commons Attribution 4.0 International License, which permits use, sharing, adaptation, distribution and reproduction in any medium or format, as long as you give appropriate credit to the original author(s) and the source, provide a link to the Creative Commons licence, and indicate if changes were made. The images or other third party material in this article are included in the article's Creative Commons licence, unless indicated otherwise in a credit line to the material. If material is not included in the article's Creative Commons licence and your intended use is not permitted by statutory regulation or exceeds the permitted use, you will need to obtain permission directly from the copyright holder. To view a copy of this licence, visit http://creativecommons.org/licenses/by/4.0/.

\section{References}

Alrøe HF, Byrne J, Glover L (2006) Organic agriculture and ecological justice: ethics and practice. In: Halberg N, Alrøe HF, Knudsen MT, Kristensen ES (eds) Global 
development of organic agriculture: Challenges and prospects. CABI, Wallingford, pp 75-112

Arzoumanidis I, D’Eusanio M, Raggi A, Petti L (2020) Functional Unit Definition Criteria in Life Cycle Assessment and Social Life Cycle Assessment: A Discussion. In: Traverso M, Petti L, Zamagni A (eds) Perspectives on Social LCA. Springer International Publishing, Cham, pp 1-10. https://doi.org/10.1007/978-3-030-01508-4_1

Bergström L, Kirchmann H (2016) Are the claimed benefits of organic agriculture justified? Nat Plants 2:16099. https:// doi.org/10.1038/nplants.2016.99

Berlin D, Uhlin H-E (2004) Opportunity cost principles for life cycle assessment: toward strategic decision making in agriculture. PIE 1:187. https://doi.org/10.1504/PIE.2004. 004678

Bisoffi S (2019) A meta-analysis of recent foresight documents in support of the 5th SCAR Foresight Exercise. https:// scar-europe.org/index.php/foresight/documents. Accessed 24 November 2020

BMEL (2019) Zukunftsstrategie ökologischer Landbau: Impulse für mehr Nachhaltigkeit in Deutschland. https:// www.bmel.de/SharedDocs/Downloads/DE/Broschueren/ ZukunftsstrategieOekologischerLandbau2019.pdf? blob=publicationFile \&v=4. Accessed 6 May 2021

Bruhn T, Herberg J, Molinengo G, Oppold D, Stasiak D, Nanz P (2019) Grounded Action Design: A Model of Scientific Support for Processes to Address Complex Challenges A Concept Developed by the Research Project Co-Creation and Contemporary Policy Advice. Potsdam. https://doi. org/10.2312/iass.2019.054

Cassman KG, Grassini P (2020) A global perspective on sustainable intensification research. Nat Sustain 3:262-268. https://doi.org/10.1038/s41893-020-0507-8

Clark M, Tilman D (2017) Comparative analysis of environmental impacts of agricultural production systems, agricultural input efficiency, and food choice. Environ Res Lett 12:64016. https://doi.org/10.1088/1748-9326/aa6cd5

Connor DJ (2018) Organic agriculture and food security: A decade of unreason finally implodes. Field Crop Res 225:128-129. https://doi.org/10.1016/j.fcr.2018.06.008

Douglas HE (2016) Science, Policy, Values: Exploring the Nexus. Perspect Sci 24:475-480. https://doi.org/10.1162/ POSC_e_00219

Douglass GK (1984) The Meanings of Agricultural Sustainability. In: Douglass GK (ed) Agricultural Sustainability in a Changing World Order. Westview Press, Boulder, CO, pp 3-29

European Commission (2020) Farm to Fork Strategy: For a fair, healthy and environmentally-friendly food system. https://ec. europa.eu/food/system/files/2020-05/f2f_action-plan_2020_ strategy-info_en.pdf. Accessed 8 November 2021

Eyhorn F, Müller A, Reganold JP, Frison E, Herren HR, Luttikholt L, Mueller A, Sanders J, Scialabba NE-H, Seufert V, Smith P (2019) Sustainability in global agriculture driven by organic farming. Nat Sustain 2:253-255. https:// doi.org/10.1038/s41893-019-0266-6

FAO (2018) FAO's work on Agroecology: A Pathway to Achieving the SDGs. https://www.fao.org/3/i9021en/ i9021en.pdf. Accessed 11 November 2021

Fess TL, Benedito VA (2018) Organic versus Conventional Cropping Sustainability: A Comparative System Analysis. Sustainability 10:272. https://doi.org/10.3390/su10010272
Fischer J, Abson DJ, van Butsic CMJ, Ekroos J, Hanspach J, Kuemmerle T, Smith HG, von Wehrden H (2014) Land Sparing Versus Land Sharing: Moving Forward. Conserv Lett 7:149-157. https://doi.org/10.1111/conl.12084

Foley JA, Ramankutty N, Brauman KA, Cassidy ES, Gerber JS, Johnston M, Mueller ND, O'Connell C, Ray DK, West PC, Balzer C, Bennett EM, Carpenter SR, Hill J, Monfreda C, Polasky S, Rockström J, Sheehan J, Siebert S, Tilman D, Zaks DPM (2011) Solutions for a cultivated planet. Nature 478:337-342. https://doi.org/10.1038/nature10452

Gabriel D, Sait SM, Kunin WE, Benton TG (2013) Food production vs. biodiversity: comparing organic and conventional agriculture. J Appl Ecol 50:355-364. https://doi. org/10.1111/1365-2664.12035

Garibaldi LA, Gemmill-Herren B, D'Annolfo R, Graeub BE, Cunningham SA, Breeze TD (2017) Farming Approaches for Greater Biodiversity, Livelihoods, and Food Security. Trends Ecol Evol 32:68-80. https://doi.org/10.1016/j.tree. 2016.10.001

Geier U (2000) Anwendung der Ökobilanz-Methode in der Landwirtschaft: Dargestellt am Beispiel einer ProzessÖkobilanz konventioneller und organischer Bewirtschaftung. Schriftenreihe Institut für Organischen Landbau, [13]. Köster, Berlin

Giller KE, Hijbeek R, Andersson JA, Sumberg J (2021) Regenerative Agriculture: An agronomic perspective. Outlook Agric 50:13-25. https://doi.org/10.1177/0030727021 998063

Goklany IM (2002) The ins and outs of organic farming. Science 298:1889-1890. https://doi.org/10.1126/science.298. 5600.1889 b

Gómez MI, Barrett CB, Raney T, Pinstrup-Andersen P, Meerman J, Croppenstedt A, Carisma B, Thompson B (2013) Post-green revolution food systems and the triple burden of malnutrition. Food Policy 42:129-138. https://doi.org/ 10.1016/j.foodpol.2013.06.009

Gomiero T, Pimentel D, Paoletti MG (2011) Environmental Impact of Different Agricultural Management Practices: Conventional vs. Organic Agriculture. Crit Rev Plant Sci 30:95-124. https://doi.org/10.1080/07352689.2011. 554355

Halberg N (2012) Assessment of the environmental sustainability of organic farming: Definitions, indicators and the major challenges. Can J Plant Sci 92:981-996. https://doi. org/10.4141/cjps2012-035

Halberg N, van der Werf HMG, Basset-Mens C, Dalgaard R, de Boer IJM (2005) Environmental assessment tools for the evaluation and improvement of European livestock production systems. Livest Prod Sci 96:33-50. https://doi. org/10.1016/j.livprodsci.2005.05.013

Haller L, Moakes S, Niggli U, Riedel J, Stolze M, Thompson M (2020) Entwicklungsperspektiven der ökologischen Landwirtschaft in Deutschland. Texte. https://www.umwel tbundesamt.de/sites/default/files/medien/1410/publikatio nen/2020-03-17_texte_32-2020_oekologische-landwirtsc haft.pdf. Accessed 29 October 2020

HLPE (2017) Nutrition and food systems: A report by the High Level Panel of Experts on Food Security and Nutrition of the Committee on World Food Security, Rome. http:// www.fao.org/3/a-i7846e.pdf. Accessed 19 November 2020 
Holt-Giménez E, Shattuck A, Altieri M, Herren H, Gliessman S (2012) We Already Grow Enough Food for 10 Billion People ... and Still Can't End Hunger. J Sustain Agric 36:595598. https://doi.org/10.1080/10440046.2012.695331

IFOAM (2021) Priciples of Organic Agriculture: Preamble. https://www.ifoam.bio/sites/default/files/2020-03/poa_ english_web.pdf. Accessed 8 November 2021

Ingram J (2020) Nutrition security is more than food security. Nat Food 1:2. https://doi.org/10.1038/s43016-019-0002-4

IPCC (2019) Summary for Policymakers. In: Shukla PR, Skea J, Calvo Buendia E, Masson-Delmotte V, Pörtner H-O, Roberts D, Zhai P, Slade R, Connors S, van Diemen R, Ferrat M, Haughey E, Luz S, Neogi S, Pathak M, Petzold J, Portugal Pereira J, Vyas P, Huntley E, Kissick K, Belkacemi M, Malley J (eds) Climate Change and Land: An IPCC special report on climate change, desertification, land degradation, sustainable land management, food security, and greenhouse gas fluxes in terrestrial ecosystems. https://www.ipcc.ch/srccl/chapter/summaryfor-policymakers/. Accessed 9 November 2021

IPES-Food (2016) From university to diversity: a paradigm shift from industrial agriculture to diversified agroecological systems. http://www.ipes-food.org/_img/upload/files/Unifo rmityToDiversity_FULL.pdf. Accessed 23 October 2020

Jespersen LM, Baggesen DL, Fog E, Halsnæs K, Hermansen JE, Andreasen L, Strandberg B, Sørensen JT, Halberg N (2017) Contribution of organic farming to public goods in Denmark. Org Agr 7:243-266. https://doi.org/10.1007/s13165-017-0193-7

Kassam A, Friedrich T, Derpsch R (2019) Global spread of Conservation Agriculture. Int J Environ Stud 76:29-51. https://doi.org/10.1080/00207233.2018.1494927

Kernecker M, Seufert V, Chapman M (2021) Farmer-centered ecological intensification: Using innovation characteristics to identify barriers and opportunities for a transition of agroecosystems towards sustainability. Agric Syst 191:103142. https://doi.org/10.1016/j.agsy.2021.103142

Kirchmann H (2019) Why organic farming is not the way forward. Outlook Agric 48:22-27. https://doi.org/10.1177/ 0030727019831702

Kirchmann H, Bergström L, Kätterer T, Mattsson L, Gesslein S (2007) Comparison of Long-Term Organic and Conventional Crop-Livestock Systems on a Previously NutrientDepleted Soil in Sweden. Agron J 99:960. https://doi.org/ 10.2134/agronj2006.0061

Kirchmann H, Kätterer T, Bergström L, Börjesson G, Bolinder MA (2016) Flaws and criteria for design and evaluation of comparative organic and conventional cropping systems. Field Crop Res 186:99-106. https://doi.org/10.1016/j.fcr.2015.11.006

Knapp S, van der Heijden MGA (2018) A global meta-analysis of yield stability in organic and conservation agriculture. Nat Commun 9:3632. https://doi.org/10.1038/ s41467-018-05956-1

Kremen C (2020) Ecological intensification and diversification approaches to maintain biodiversity, ecosystem services and food production in a changing world. Emerg Top Life Sci 4:229-240. https://doi.org/10.1042/ETLS20190205

Kremen C (2015) Reframing the land-sparing/land-sharing debate for biodiversity conservation. Ann N Y Acad Sci 1355:52-76. https://doi.org/10.1111/nyas.12845
Kuckartz U (2018) Qualitative Inhaltsanalyse. Methoden, Praxis, Computerunterstützung, 4th edn. Grundlagentexte Methoden. Beltz Juventa, Weinheim

Kusche D, Hoppe J, Hupe A, Heß J (2019) Wasserschutz. In: Sanders J, Heß J (eds) Leistungen des ökologischen Landbaus für Umwelt und Gesellschaft. Johann Heinrich von Thünen-Institut, Braunschweig, pp 59-91

Kuyper TW, Struik PC (2014) Epilogue: global food security, rhetoric, and the sustainable intensification debate. Current Opinion in Environmental Sustainability 8:71-79. https://doi.org/10.1016/j.cosust.2014.09.004

LaCanne CE, Lundgren JG (2018) Regenerative agriculture: merging farming and natural resource conservation profitably. PeerJ 6:e4428. https://doi.org/10.7717/peerj.4428

Lal R (2020) Regenerative agriculture for food and climate. J Soil Water Conserv 75:123A-124A. https://doi.org/10. 2489/jswc.2020.0620A

Leifeld J (2016) Current approaches neglect possible agricultural cutback under large-scale organic farming. A comment to Ponisio et al. Proc Biol Sci 283(1824):2015-1623. https://doi.org/10.1098/rspb.2015.1623

Lorenz K, Lal R (2016) Environmental Impact of Organic Agriculture. Adv Agron 139:99-152. https://doi.org/10. 1016/bs.agron.2016.05.003

Mäder P, Fließbach A, Dubois D, Gunst L, Fried P, Niggli U (2002) The ins and outs of organic farming [Response]. Science 298:1889-1890. https://doi.org/10.1126/science. 298.5600.1889b

Mayring P (2015) Qualitative Inhaltsanalyse: Grundlagen und Techniken, 12th edn. Beltz Pädagogik. Beltz, Weinheim

Meemken E-M, Qaim M (2018) Organic Agriculture, Food Security, and the Environment. Annu Rev Resour Econ 10:39-63. https://doi.org/10.1146/annurev-resou rce-100517-023252

Mehrabi Z, Seufert V, Ramankutty NThe Conventional Versus Alternative Agricultural Divide: A Response to Garibaldi, et al (2017) Trends Ecol Evol 32:720-721. https://doi.org/ 10.1016/j.tree.2017.07.011

Meng F, Qiao Y, Wu W, Smith P, Scott S (2017) Environmental impacts and production performances of organic agriculture in China: A monetary valuation. J Environ Manage 188:49-57. https://doi.org/10.1016/j.jenvman.2016.11.080

Moher D, Liberati A, Tetzlaff J, Altman DG (2009) Preferred reporting items for systematic reviews and meta-analyses: the PRISMA statement. PLoS Med 6:e1000097. https:// doi.org/10.1371/journal.pmed.1000097

Müller A, Bautze L, Meier M, Gattinger A, Gall E, Chatzinikolaou E, Meredith S, Ukas T, Ullmann L (2016) Organic farming, climate change mitigation and beyond: Reducing the environmental impacts of EU agriculture, Brussels. https://www.ifoam-eu.org/sites/default/files/ ifoameu_advocacy_climate_change_report_2016.pdf. Accessed 3 May 2020

Müller A, Schader C, El-Hage Scialabba N, Brüggemann J, Isensee A, Erb K-H, Smith P, Klocke P, Leiber F, Stolze M, Niggli U (2017) Strategies for feeding the world more sustainably with organic agriculture. Nat Commun 8:1290. https://doi.org/10.1038/s41467-017-01410-w

Nielsen JØ, de Bremond A, Roy Chowdhury R, Friis C, Metternicht G, Meyfroidt P, Munroe D, Pascual U, Thomson A (2019) Toward a normative land systems science. 
Current Opinion in Environmental Sustainability 38:1-6. https://doi.org/10.1016/j.cosust.2019.02.003

Niggli U (2015) Sustainability of organic food production: challenges and innovations. Proc Nutr Soc 74:83-88. https://doi.org/10.1017/S0029665114001438

Page KL, Dang YP, Dalal RC (2020) The Ability of Conservation Agriculture to Conserve Soil Organic Carbon and the Subsequent Impact on Soil Physical, Chemical, and Biological Properties and Yield. Front Sustain Food Syst 4:17. https://doi.org/10.3389/fsufs.2020.00031

Ponisio L, Ehrlich P (2016) Diversification, Yield and a New Agricultural Revolution: Problems and Prospects. Sustainability 8:1118. https://doi.org/10.3390/su8111118

Ponisio LC, Kremen C (2016) System-level approach needed to evaluate the transition to more sustainable agriculture. Proc Biol Sci 283:20152913. https://doi.org/10.1098/rspb. 2015.2913

Ponisio LC, M'Gonigle LK, Mace KC, Palomino J, de Valpine P, Kremen C (2015) Diversification practices reduce organic to conventional yield gap. Proc Biol Sci 282:20141396. https://doi.org/10.1098/rspb.2014.1396

de Ponti T, Rijk B, van Ittersum MK (2012) The crop yield gap between organic and conventional agriculture. Agric Syst 108:1-9. https://doi.org/10.1016/j.agsy.2011.12.004

Pretty J, Benton TG, Bharucha ZP, Dicks LV, Flora CB, Godfray HCJ, Goulson D, Hartley S, Lampkin N, Morris C, Pierzynski G, Prasad PVV, Reganold J, Rockström J, Smith P, Thorne P, Wratten S (2018) Global assessment of agricultural system redesign for sustainable intensification. Nat Sustain 1:441-446. https://doi.org/10.1038/ s41893-018-0114-0

Reganold JP, Wachter JM (2016) Organic agriculture in the twenty-first century. Nat Plants 2:15221. https://doi.org/ 10.1038/nplants.2015.221

Sanders J (2016) Agrarpolitik. In: Freyer B (ed) Ökologischer Landbau: Grundlagen, Wissensstand und Herausforderungen. Haupt Verlag, Bern, pp 279-297

Sanders J, Heß J (eds) (2019) Leistungen des ökologischen Landbaus für Umwelt und Gesellschaft. Thünen-Report, vol 65. Johann Heinrich von Thünen-Institut, Braunschweig. https://doi.org/10.22004/ag.econ.298449

Schader C, Stolze M, Gattinger A (2012) Environmental performance of organic farming. In: Boye JI, Arcand Y (eds) Green technologies in food production and processing. Springer, New York, pp 183-210

Scoones I, Smalley R, Hall R, Tsikata D (2019) Narratives of scarcity: Framing the global land rush. Geoforum 101:231241. https://doi.org/10.1016/j.geoforum.2018.06.006

Searchinger TD, Wirsenius S, Beringer T, Dumas P (2018) Assessing the efficiency of changes in land use for mitigating climate change. Nature 564:249-253. https://doi. org/10.1038/s41586-018-0757-z

Seufert V (2019) Comparing Yields: Organic Versus Conventional Agriculture. In: Ferranti P, Berry E, Jock A (eds) Encyclopedia of Food Security and Sustainability. Elsevier, San Diego, pp 196-208. https://doi.org/10.1016/ B978-0-08-100596-5.22027-1
Seufert V, Ramankutty N (2017) Many shades of gray-The context-dependent performance of organic agriculture. Sci Adv 3:e1602638. https://doi.org/10.1126/sciadv.1602638

Seufert V, Ramankutty N, Foley JA (2012) Comparing the yields of organic and conventional agriculture. Nature 485:229-232. https://doi.org/10.1038/nature11069

Shennan C, Krupnik TJ, Baird G, Cohen H, Forbush K, Lovell RJ, Olimpi EM (2017) Organic and Conventional Agriculture: A Useful Framing? Annu Rev Environ Resour 42:317-346. https://doi.org/10.1146/annurev-envir on-110615-085750

Steffen W, Richardson K, Rockström J, Cornell SE, Fetzer I, Bennett EM, Biggs R, Carpenter SR, de Vries W, de Wit CA, Folke C, Gerten D, Heinke J, Mace GM, Persson LM, Ramanathan V, Reyers B, Sörlin S (2015) Sustainability. Planetary boundaries: guiding human development on a changing planet. Science 347:1259855. https://doi.org/10.1126/science. 1259855

Stein-Bachinger K, Haub A, Gottwald F (2019) Biodiversität. In: Sanders J, Heß J (eds) Leistungen des ökologischen Landbaus für Umwelt und Gesellschaft. Johann Heinrich von Thünen-Institut, Braunschweig, pp 129-163

Stolze M (2000) The environmental impacts of organic farming in Europe. Organic farming in Europe economics and policy, vol 6. Inst. für Landwirtschaftliche Betriebslehre, Stuttgart-Hohenheim

Struik PC, Kuyper TW, Brussaard L, Leeuwis C (2014) Deconstructing and unpacking scientific controversies in intensification and sustainability: why the tensions in concepts and values? Current Opinion in Environmental Sustainability 8:80-88. https://doi.org/10.1016/j.cosust. 2014.10.002

Tal A (2018) Making Conventional Agriculture Environmentally Friendly: Moving beyond the Glorification of Organic Agriculture and the Demonization of Conventional Agriculture. Sustainability 10:1078. https://doi. org/10.3390/su10041078

Thompson PB (2010) The agrarian vision: Sustainability and environmental ethics. University Press of Kentucky, Lexington, Ky, Culture of the land

Tittonell PA (2013) Farming systems ecology: Towards ecological intensification of world agriculture. Wageningen Universiteit, Wageningen

Trewavas A (2001) Urban myths of organic farming. Nature 410:409-410. https://doi.org/10.1038/35068639

Tuck SL, Winqvist C, Mota F, Ahnström J, Turnbull LA, Bengtsson J (2014) Land-use intensity and the effects of organic farming on biodiversity: a hierarchical metaanalysis. J Appl Ecol 51:746-755. https://doi.org/10. 1111/1365-2664.12219

Tuomisto HL, Hodge ID, Riordan P, Macdonald DW (2012) Does organic farming reduce environmental impacts? - A metaanalysis of European research. J Environ Manage 112:309320. https://doi.org/10.1016/j.jenvman.2012.08.018

van der Werf HMG, Knudsen MT, Cederberg C (2020) Towards better representation of organic agriculture in life cycle assessment. Nat Sustain 3:419-425. https:// doi.org/10.1038/s41893-020-0489-6 
Veerman C, Pinto-Correia T, Bastioli C, Biro B, Bouma J, Cienciala E, Emmett B, Frison EA, Grand A, Hristov L, Kriaučiūnienė Z, Pogrzeba M, Soussana J-F, Vela C, Wittkowski R (2020) Caring for soil is caring for life: Ensure $75 \%$ of soils are healthy by 2030 for healthy food, people, nature and climate : interim report of the mission board for soil health and food. Publications Office of the European Union, Luxembourg

VERBI Software (2019) MAXQDA 2020, Berlin. https:// www.maxqda.com/

WBAE (2020) Politik für eine nachhaltigere Ernährung: Eine integrierte Ernährungspolitik entwickeln und faire Ernährungsumgebungen gestalten, Berlin. https://www. bmel.de/SharedDocs/Downloads/DE/_Ministerium/ Beiraete/agrarpolitik/wbae-gutachten-nachhaltige-ernae hrung.html. Accessed 8 November 2021
WBGU (2020) Landwende im Anthropozän: Von der Konkurrenz zur Integration, Berlin. https://www.wbgu.de/ de/publikationen/publikation/landwende. Accessed 8 November 2021

Publisher's note Springer Nature remains neutral with regard to jurisdictional claims in published maps and institutional affiliations. 